Molecules 2009, 14, 321-328; DOI: 10.3390/molecules14010321

\title{
Communication
}

\section{Antimicrobial Activity of Some Water Plants from the Northeastern Anatolian Region of Turkey}

\author{
Hanife Özbay ${ }^{1, *}$ and Ahmet Alim ${ }^{2}$
}

1 Kafkas University, Faculty of Science, Department of Biology 36100 Kars, Turkey

2 Public Health Laboratory 58100 Sivas, Turkey

* Author to whom correspondence should be addressed; E-mail: hanifeozbay@gmail.com, Tel: +90 474 2120201/3084; Fax: +90 4742122706.

Received: 22 November 2008; in revised form: 29 December 2008 / Accepted: 5 January 2009/ Published: 12 January 2009

\begin{abstract}
The antimicrobial activity of methanol and acetone extracts of Butomus umbellatus, Polygonum amphibium, and two species of the genus Sparganium (S. erectum and S. emersum) against three Gram-positive, five Gram-negative bacteria and one fungus was assessed by the disk diffusion method. The microorganisms used were Staphylococcus aureus ATCC-29740, Escherichia coli ATCC-25922, Pseudomonas aeruginosa ATCC15442, Salmonella typhi NCTC-9394, Klebsiella pneumoniae NCTC-5046, Proteus vulgaris ATCC-7829, Bacillus subtilis ATCC-6633, Corynebacterium diphteriae RSHM633 and Candida albicans ATCC-10231. Methanol extracts of the plants did not exhibit any inhibitory activity against any of the microorganisms, while the acetone extracts of the all tested plants only showed significant activity against Bacillus subtilis, with inhibition zones and minimal inhibitory concentration values in the $7-16 \mathrm{~mm}$ and $0.49-12.50 \mathrm{mg} / \mathrm{mL}$ ranges, respectively.
\end{abstract}

Keywords: Antimicrobial activity; Butomus umbellatus; Polygonum amphibium L. (Persicaria amphibian L.); Sparganium emersum; Sparganium erectum. 


\section{Introduction}

Interest in plant-derived drugs has been increasing, mainly due to the current widespread belief that "green medicine" is safer and more dependable than costly synthetic drugs, many of which have adverse side effects [1].

The monotypic genus Butomus is the only member of the Butomaceae family, which is allied to Alismataceae and the non-European Limnocharitaceae [2]. The genus is widespread in the flora of Turkey and is represented by one species [3]. B. umbellatus L. is known as su meneksesi in Turkey and grows as a submerged or emergent aquatic or as a terrestrial species near the water's edge. It has edible tubers that contain more than 50\% starch. The seed is also edible [4-6]. Literature describing the chemical and antimicrobial activity of the genus Butomus is not available at present.

The genus Polygonum (Polygonaceae) consists of about 300 species, which are distributed worldwide, mostly in the Northern temperate region [7]. The diversity of the genus Polygonum, which comprises 25 species, is not well known in the aquatic habitats of Turkey, but it has been recorded in the eastern part of the country [8]. P. amphibium is known as su cobandegnegi in Turkey. As an aquatic, P. amphibium L. grows in standing or slowly moving water in lakes, reservoirs, canals, ditches, large fenland drains and sluggish streams and rivers [2].

In folk medicine and culture, $P$. amphibium has been valued for its tannin content, as a diuretic, as a cheap substitute for sarsaparilla in the USA [9], and as a source of yellow dye in the Shetland and Fair Isles [10]. The whole plant, especially the root, has an astringent, depurative skin [11,12]. An infusion of the leaves and stems is used to treat stomach pains and children with diarrhoea [13]. The root can be eaten raw, and an infusion of the dried, pounded roots is used in the treatment of chest colds [13]. A poultice of the fresh roots is applied directly to the mouth to treat blisters [13]. Compounds such as flavonoids [14-17], triterponoids [18], anthraquinones [19,20], coumarins [21], phenylpropanoids [22,23], lignans [24], sesquiterponoids [25], stilbenoids [26] and tannins [7] were identified in several species of Polygonum. Although chemical data is available at the generic level, information on the microbial properties or chemical composition of $P$. amphibium is not available in the literature.

There are 14 species in the genus Sparganium, all of them aquatic perennial herbs [2]. Three species have been identified in Turkey [27]. S. erectum L. is known as dik sigırsazı in Turkey. Another Sparganium species, S. emersem Rehmann, is known in Turkey as yalın sıgırsazı. In folk medicine an infusion of whole S. erectum mixed with other plant leaves has been used in the treatment of chills [13]. Some species belonging to the genus Sparganium contain a variety of metabolites. including flavonoids, essential oil, phenylpropanoid glycosides and aromatic alkenes [28]. No literature about the antimicrobial activity of the genus Sparganium is available.

All submersed aquatic angiosperms are secondarily adapted for life in water. Unlike their terrestrial counterparts, where water is a persistent feature only in the subsoil environment, submersed aquatic angiosperms are surrounded by water. Submersed aquatic angiosperms have attracted the interest of researchers because they show promise as antimicrobial agents [29, 30].

Although the antimicrobial activities and other properties of numerous terrestrial angiosperms have received a great deal of attention, perhaps because of their extensive occurrence, so far, aquatic angiosperms from rivers, lakes etc. have received less attention. In this preliminary antimicrobial assay, we now wish to report on the antimicrobial activity of the methanol and acetone extracts of the aquatic plants $P$. amphibium, B. umbellatus, S. emersum, and S. erectum. 


\section{Results and Discussion}

The inhibitory activities of the extracts of S. erectum and S. emersum, B. umbellatus and $P$. amphibium are given in Table 1. Acetone extracts of the whole plant of S. erectum, S. emersum, $P$. amphibium and B. umbellatus were inactive against Staphylococcus aureus, Escherichia coli, Pseudomonas aeruginosa, Salmonella typhi, Proteus vulgaris and Corynebacterium diphteriae bacterial species, as well as a fungal species. However, acetone extracts of all tested plants were active against B. subtilis. Inhibition zones of S. erectum, B. umbellatus, S. emersum and P. amphibium for B. subtilis were 16, 12, 7 and $12 \mathrm{~mm}$ respectively. The highest inhibition zone was produced by the extract of S. emersum. MIC's of the plant extracts for B. subtilis were $0.49 \mathrm{mg} / \mathrm{mL}$ (S. erectum), 2.50 $\mathrm{mg} / \mathrm{mL}$ (B. umbellatus), $12.50 \mathrm{mg} / \mathrm{mL}$ (S. emersum) and $2.30 \mathrm{mg} / \mathrm{mL}$ (P. amphibium). The lowest MIC was observed with the extract from $S$. erectum. On the other hand no inhibitory activities have been determined with the methanol extracts of the plants against any of the microorganisms tested (data not shown).

Table 1. Results of the antimicrobial activities of the whole plant extract of S. erectum, $B$. umbellatus, S. emersum, and P. amphibium.

\begin{tabular}{|c|c|c|c|c|c|c|}
\hline \multirow[b]{2}{*}{ Microorganizms } & \multicolumn{3}{|c|}{${ }^{\mathrm{a}} \mathbf{D D}$} & \multirow[b]{2}{*}{ P. amphibium } & \multirow[b]{2}{*}{ Gen $^{b}$} & \multirow[b]{2}{*}{ Nys $^{c}$} \\
\hline & S. erectum & B. umbellatus & S. emersum & & & \\
\hline Staphylococcus aureus & - & - & - & - & $23 \pm 0.76$ & - \\
\hline Escherichia coli & - & - & - & - & $16 \pm 0.96$ & - \\
\hline Pseudomonas aeruginosa & - & - & - & - & $20 \pm 1.06$ & - \\
\hline Salmonella typhi & - & - & - & - & $10 \pm 0.45$ & - \\
\hline Klebsiella pneumonia & - & - & - & - & $20 \pm 0.70$ & - \\
\hline Proteus vulgaris & - & - & - & - & $22 \pm 1.40$ & - \\
\hline Bacillus subtilis & $16 \pm 0.8$ & $12 \pm 1.4$ & $7 \pm 1.4$ & $12 \pm 0.8$ & $29 \pm 1.15$ & - \\
\hline $\begin{array}{l}\text { Corynebacterium } \\
\text { diphteriae }\end{array}$ & - & - & - & - & $23 \pm 1.10$ & - \\
\hline Candida albicans & - & - & - & - & - & $25 \pm 0.90$ \\
\hline \multicolumn{7}{|c|}{ MIC (mg/mL) } \\
\hline Bacillus subtilis & 0.49 & 2.50 & 12.50 & 2.30 & & \\
\hline
\end{tabular}

${ }^{\mathrm{a}} \mathrm{DD}$, agar disc diffusion method. Diameter of inhibition zone $(\mathrm{mm})$ including disk diameter of $6 \mathrm{~mm}$.

${ }^{\mathrm{b}}$ Gentamycin (antibacterial).

${ }^{\mathrm{c}}$ Nystatin (antifungal).

According to MIC values, S. erectum extracts showed moderate activity against $B$. subtilis while the other three extracts were inactive [31]. All tested plant extracts only inhibited the growth of B. subtilis. Although they may contain common chemical constituents [28] two species of Sparganium belonging to the Sparganiaceae family revealed different inhibition zones and MIC's for B. subtilis. These differences could be due to their different habitats, as S. erectum grows at the edge of waters as an emergent species while $S$. emersum grows in water with 0.2-1 $\mathrm{m}$ deep as a submersed plant. Because submersed aquatic angiosperms are secondarily adapted to life in water, their antimicrobial activity may possible increase with the increasing terrestrial life contact. 
In contrast to our findings on P. amphibium, numerous authors have reported various degrees of antibacterial and antifungal activity of the various crude extracts obtained from the genus Polygonum belonging to the Polygonaceae family. In an earlier antifungal assay, Mohamed et al. [32] examined the antimycotic activity of an $80 \%$ ethanol extract of $P$. minus against seven fungal species and they reported inhibitory activity only against $A$. alternate. In another antifungal screen, dichloromethane and methanol extracts of $P$. hydropiperoides were tested against eleven fungal species. Unlike the methanol extract, the dichloromethane extract was effective against $C$. albicans, $C$. cladosporioides, $C$. neoformans, and M. gypseum [33]. On the other hand inhibitory activities of dichloromethane, methanol, $50 \%$ of ethanol and aqueous extracts of $P$. punctatum were tested against $B$. subtilis, $M$. luteus, S. aureus, E. coli, P. aeruginosa, C. albicans, Mucor spp., and A. niger [34] and the methanol extract only showed activity against $B$. subtilis. Our study, in which we did not observe any antimicrobial activity with methanol extracts, appears to match this finding. Similarly in a recent study ether, ethanol and hot water extracts of P. cognatum were tested against S. aureus, B. subtilis, E. coli, $P$. aeruginosa and C. albicans. Inhibitory effects of the ether and ethanol extracts were found against S. aureus and B. subtilis [35]. The extraction procedure, solvent type and species differences might be the reason for the differences in antimicrobial effects against the test organisms as exhibited by the genus Polygonum.

Unlike the acetone one, the methanol extract revealed no significant inhibitory activity against any of the microorganisms and we may conclude that the active compounds in our test plants reside in acetone extracts rather than methanol extracts, and that acetone seems to be better than methanol for extracting antimicrobial compounds from medicinal plants. Eloff reported similar findings for extracting of antimicrobial compounds from some medicinal plants [36]. He suggested that acetone dissolves many hydrophilic and lipophilic components from the medicinal plants, is miscible with water, is volatile and has a low toxicity to the bioassay used [36].

\section{Conclusions}

The present results suggest that there are many unexploited plants and natural compounds in aquatic plant species that could be potential resources for the reduction or control of bacterial diseases. Therefore, further studies should be undertaken to characterise the active compounds residing in these types of plants. Additionally, evaluation of the effects of each individual compound on microorganisms as well as toxicological studies need to be performed.

\section{Experimental}

\section{Plant material}

Collection of all test plants took place between June and July 2006. S. erectum, S. emersum and B. umbellatus were collected from Çali Lake $\left(40^{\circ} 31^{\prime} \mathrm{N}, 43^{\circ} 15^{\prime} \mathrm{E}\right)$ and $P$. amphibium was collected from Aktaş Lake $\left(41^{\circ} 12^{\prime} \mathrm{N}, 43^{\circ} 12^{\prime} \mathrm{E}\right)$. 


\section{Preparation of extracts}

After collection, all parts of the plant material were cleaned with tap water and then with distilled water. Plants were air dried at ambient temperature and powdered with a Waring blender. Plant material was extracted by using a Soxlet extractor with solvents of increasing polarity beginning with acetone, followed by methanol (Merck, Darmstadt). The solvents used in this work were purified [37] before extraction. Extraction of each plant powder $(20 \mathrm{~g})$ was done at room temperature $150 \mathrm{ml}$ solvent. Extraction with each solvent was carried out for 8 to $10 \mathrm{~h}$.

\section{Antimicrobial assay}

The antimicrobial and antifungal activity of the acetone extract was evaluated against three Grampositive, five Gram-negative bacteria and one fungus by the disk diffusion method. The microorganisms used were Staphylococcus aureus ATCC-29740, Escherichia coli ATCC-25922, Pseudomonas aeruginosa ATCC-15442, Salmonella typhi NCTC-9394, Klebsiella pneumoniae NCTC-5046 , Proteus vulgaris ATCC-7829, Bacillus subtilis ATCC-6633, Corynebacterium diphteriae RSHM-633 and Candida albicans ATCC-10231. Cultures were obtained from the culture collections of the Department of Health of Refik Saydam Hygiene Centre, Contagious Diseases Research Department (Ankara, Turkey). Bacterial strains were cultured overnight at $37{ }^{\circ} \mathrm{C}$ in Mueller Hinton Agar (Oxoid-CM 337). Yeast was cultured overnight at $30{ }^{\circ} \mathrm{C}$ in Sabouraud dextrose agar (Oxoid-CM41). All the experiments were carried out in triplicate and the average and standard deviation (SD) were calculated for the inhibition zone diameters.

The agar disc diffusion method was employed for the determination of antimicrobial activities of the extract [38]. Briefly, a suspension of the tested microorganism $\left(0.1 \mathrm{~mL} 10^{8}\right.$ cells per $\left.\mathrm{mL}\right)$ was spread on the solid media plates. Filter paper discs (6 mm in diameter) were impregnated with $15 \mu \mathrm{L}$ of the extract and placed on the inoculated plates. These plates, after staying at $4{ }^{\circ} \mathrm{C}$ for $2 \mathrm{~h}$, were incubated at $37{ }^{\circ} \mathrm{C}$ for $24 \mathrm{~h}$ for bacteria and at $30{ }^{\circ} \mathrm{C}$ for $48 \mathrm{~h}$ for the yeast. The diameters of the inhibition zones were measured in millimetres.

A broth microdilution susceptibility assay was used, as recommended by NCCLS, for the determination of MIC [39]. All tests were performed in Mueller Hinton broth (MHB; OXOID-CM405) with the exception of the yeasts (Sabouraud dextrose broth-SDB; DIFCO). Bacterial strains were cultured overnight at $37^{\circ} \mathrm{C}$ in MHA (Mueller Hinton Agar) and the yeasts were cultured overnight at $30{ }^{\circ} \mathrm{C}$ in SDA (Sabouraud dextrose agar). Test strains were suspended in MHB to give a final density of $5 \times 10^{5} \mathrm{cfu} / \mathrm{mL}$ and these were confirmed by viable counts. Geometric dilutions ranging from $1 / 2$ $\mathrm{mg} / \mathrm{mL}$ to $1 / 6,400 \mathrm{mg} / \mathrm{mL}$ of the extract were prepared in a 96 -well microtiter plate, including one growth control and one sterility control. Plates were incubated under normal atmospheric conditions at $37{ }^{\circ} \mathrm{C}$ for $24 \mathrm{~h}$ for bacteria and at $30{ }^{\circ} \mathrm{C}$ for $48 \mathrm{~h}$ for the yeasts. The MIC of amikacin, clindamycine and ciprofloxacine was individually determined in parallel experiments in order to control the sensitivity of the test organisms. Bacterial growth was indicated by the presence of a white "pellet" on the well bottom. 


\section{References}

1. Parekh, J.; Chanda, S. In-vitro Antimicrobial Activities of Extracts of Launea procumbens Roxb. (Labiateae), Vitis vinifera L. (Vitaceae) and Cyperus rotundus L. (Cyperaceae). Afr. J. Biomed. Res. 2006, 9, 89-93.

2. Preston, C.D.; Croft, J.M. Aquatic plants in Britain and Ireland. Botanical Society of the British Isles (BSBI): Colchester, 1997; pp. 70-312.

3. Altinayar, G. Water Weeds. State Hydraulic Work Department Publishing: Ankara, Turkey, 1988; pp. 69-148.

4. Huxley, A. The New RHS Dictionary of Gardening. Nature Publishing Group: London, UK, 1999; pp. 31-1633.

5. Hedrick, U.P. Sturtevant's Edible Plants of the World. Dover Publications: New York, USA, 1972; pp. 56-512.

6. Mabey, R. Food for free: Edible wild plants find in Britain. Collins: London, UK, 1974; pp.16123.

7. Wang, K.; Zhang. Y.J.; Yang,C.H. Antioxidant phenolic compounds from rhizomes of Polygonum paleaceum. J. Etnopharmacol. 2005, 96, 483-487.

8. Davis, P.H. Flora of Turkey and The East Eagean Islands. Edinburgh University Press: Edinburgh, UK, 1967; Vol. 2, pp. 266-293.

9. Millspaugh, C.F. American Medicinal Plants. Dover: New York, NY, USA, 1974; pp. 86-603.

10. Scot, W.A.; Palmer, R. The Flowering Plants and Ferns of the Scotland Islands. The Shetland Times: Lerwick, UK, 1987; p. 300.

11. Singh, G.; Kachroo, P. Forest Flora of Srinagar and Plants of Neighborhood. Bishen Singh Mahendra PalSingh: Delhi, India, 1976; pp. 27-218.

12. Coffey, T. The History and Folklore of North American Wild Flowers. Houghton Mifflin: Boston, USA, 1994; pp. 36-189.

13. Moerman, D. Native American Ethnobotany. Timber Press: Portland, Oregon, USA, 1998; pp. $42-$ 691.

14. Sartor, C.; da Silva, C.; de Souza, M. Flavonoid glycosides of Polygonum stelligerum Cha. Biochem. System. Ecol. 1999, 27, 303-304.

15. Datta, B.; Datta, S.; Rashid, M.; Sarker, S. Flavonoids from Polygonum stagninum (Polygonaceae). Biochem. System. Ecol. 2002, 30, 693-696.

16. Peng, Z.; Strack, D.; Baumert, A.; Subramaniam, R.; Goh, N.; Chia, T.; Tan, S.; Chia, L. Antioxidant flavonoids from leaves of Polygonum hydropiper L. Phytochemistry 2003, 62, 219228.

17. Lopez, S.N.; Gonzalez, Sierrs, M.; Gattuso, S.J; Furlan, R.L.; Zacchino, S.A. An unusual homoisoflavonone and structurally-related dihydrochalcone from Polygonum ferrugineum (Polygonaceae). Phytochemistry 2006, 67, 2152-2158.

18. Duwiejua, M.; Zeitlin,; Gray, A.; Waterman, P. The anti-inflammatory compounds of Polygonum bistorta: isolation and characterization. Planta Med. 1999, 65, 371-374.

19. Matsuda, H.; Shimoda, H.; Morikawa, T.; Yoshikawa, M. Phytoestergons from the roots of Polygonum cuspidatum (Polygonaceae): structure requirement of hydroxyanthrquinones for estrogenic activity. Bioorg. Med. Chem. Lett. 2001, 11, 1839-1842. 
20. Yim, T.; Wu, W.; Mak, D.; Ko, K. Myocardial protective effect of an anthraquinone extract of Polygonum multiflorum in vivo. Planta Med. 1998, 64, 607-611.

21. Sun, X.; Sneden, A. Neoflavonoids from Polygonum perfoliatum. Planta Med. 1999, 65, 671-673.

22. Murai, Y.; Kashimura, S.; Tamezawa, S.; Hashimoto, T.; Takaoka, S.; Asakawa, Y.; Kiguchi, K.; Murai, F.; Tagawa, M. Absolute configuration of $(6 \mathrm{~S}, 9 \mathrm{~S})$ roseoside from Polygonum hydropiper. Planta Med. 2001, 67, 480-481.

23. Takasaki, M.; Konoshima, T.; Kuroki, S.; Tokuda, H.; Nishino, H. Cancer chemopreventive activity of phenylpropanoid esters of sucrose vanicoside B and lapathoside A from Polygonum lapathifolium. Cancer Lett. 2001, 173, 133-138.

24. Kim, H.; Woo, E.; Park, H. A novel lignan and flavonoids from Polygonum aviculare. J. Nat. Prod. 1994, 57, 581-586.

25. Datta, B.; Datta, S.; Rashid, M.; Nash, R.; Sarker, S. A sesquiterpene acid and flavonoids from Polygonum viscosum. Phytochemistry 2000, 54, 201-205.

26. Nonaka, G.; Miwa, N.; Nishioka, I. Stilbene glycoside gallates and proanthocyanidins from Polygonum multiflorum. Phytochemistry 1982, 21, 429-432.

27. Davis, P.H. Flora of Turkey and The East Eagean Islands. Edinburgh University Press: Edinburgh, UK, 1984; Vol. 8, pp. 299-356.

28. Hua, H.; Yuan, T.; Wang, Y.; Pei, Y. A new aromatic alkine from the tuber of Sparganium stolineferum. Fitoterapia 2007, 78, 274-275.

29. Morales, J.L.; Cantillo-Ciau, Z.O.; Sanchez-Molina, I.; Mena-Rejon, G.J. Screening of antibacterial and antifungal activities of six marine macroalgae from coasts of Yucatan peninsula. Pharm. Biol. 2006, 44, 632-635.

30. Bushmann, P.J.; Ailstok, M.S. Antibacterial compounds in estuarine submersed aquatic plants. $J$. Exp. Mar. Biol. Ecol. 2006, 331, 41-50.

31. Morales, G.; Porades, A.; Sierra, P.; Coyola, L. Antmicrobial Activity of three Baccharis Species Used in the Traditinal Medicine of Northern Chile. Molecules 2008, 13, 790-794.

32. Mohamed, S.; Saka, S.; El-Sharkawy, S.H.; Ali, A.M.; Muid, S. Antimycotic screening of 58 Malasian plants against plant pathogens. Pesticide Sci. 1996, 47, 259-264.

33. Freixa, B.; Vila, R.; Vargasa, L.; Lozano, N.; Adzet, T.; Caniguera, S. Screening for antifungal activity of nineteen Latin American Plants. Phytother. Res. 1998, 12, 427-430.

34. Penna, C.; Marino, S.; Vivot, E.; Cruanes, M.C.; Munoz, J.; Cruanes, J.; Ferraro, G.; Gutkind, G.; Martino, V. Antimicrobial activity of Argentine plants used in the treatment of infectious diseases. Isolation of active compounds from Sebastiana brasiliensis. J. Ethnopharmacol. 2001, 77, 37-40.

35. Yildirim, A.; Mavi, A.; Kara, A.A. Antioxidant and antimicrobial activities of Polygonum cognatum Meissn extracts. J. Sci. Food. Agric. 2003, 83, 64-69.

36. Eloff, J.N. Which extractant should be used for the screening and isolation of antimicrobial components from plants. J. Ethnopharmacol. 1998, 60, 1-8.

37. Perrin, D.D.; Armarego, W.L.F. Purification of Labrotory Chemicals, $3^{\text {rd }}$ Ed.; Pergamon Press: Oxford, UK, 1988; pp. 68-217.

38. Bradshaw, L.J. Laboratory of Microbiology, $4^{\text {th }}$ Ed; S Saunders College Publishing: Philadelphia, USA, 1992; pp. 34-121. 
39. NCCLS. Methods for determining bacteridical activity of antimicrobial agents, Proposed guideline, 1999.

Sample Availability: Available from the corresponding authors.

(C) 2009 by the authors; licensee Molecular Diversity Preservation International, Basel, Switzerland. This article is an open-access article distributed under the terms and conditions of the Creative Commons Attribution license (http://creativecommons.org/licenses/by/3.0/). 